DOI: https://doi.org/10.18371/fp.3(35).2019.190155

УДК 336

\title{
ФІНАНСОВА БЕЗПЕКА БАНКІВСЬКОЇ ДІЯЛЬНОСТІ: СУТНІСНИЙ ТА ЗАБЕЗПЕЧУВАЛЬНИЙ АСПЕКТИ
}

\author{
КВАСНИЦЬКА Раїса Степанівна \\ Дочент, доктор економічних наук, \\ професор, Хмельницький національний університет \\ ORCID ID: http://orcid.org/0000-0002-0443-9390 \\ e-mail: rstepanivna@gmai.com
}

\section{АНТОНЮК Олександра Володимирівна}

студентка, Хмельницький національний університет e-mail:antoniukav@gmail.com

\begin{abstract}
Анотація. $B$ статті обтрунтовано сутність фінансової безпеки банків, досліджено ризики, щчо впливають на фінансову безпеку банківської діяльності. Розкрито суть моральних ризиків та запропоновано їх розгляд за впливом на них різних факторів. Визначено інструментарій, який дає змогу здійснювати діагностичні і превентивні діï, спрямовані на підтримку належного рівня фінансової безпеки. Сформульовано заходи щзодо забезпечення фінансової безпеки банківських установ.

Ключові слова: фінансова безпека банків, система фінансової безпеки, моральні ризики, рівень фінансової безпеки, інструменти забезпечення фінансової безпеки.
\end{abstract}

Постановка проблеми. Якість роботи окремих банків та ефективне функціонування банківської системи здійснюють вагомий вплив на рівень життя та платоспроможність населення, на фінансовий стан суб'єктів господарювання та на розвиток еко
Аннотация. B cmamье обоснована сущность финансовой безопасности банков, исследованы риски, влияющие на финансовую безопасность банковской деятельности. Раскрыта суть морального ущерба и предложено их рассмотрение по влиянию на них различных факторов. Определен инструментарий, который позволяет осуществлять диагностические и превентивные действия, направленные на поддержание надлежащего уровня финансовой безопасности. Сформулированы меры по обеспечению финансовой безопасности банковских учреждений.

Ключевые слова: финансовая безопасность банков, система финансовой безопасности, моральные риски, уровень финансовой безопасности, инструменть обеспечения финансовой безопасности.

номіки держави загалом. Тому сучасні банки повинні докладати великих зусиль для розробки комплексних та дієвих систем власної економічної безпеки, і особливу увагу звертати на фінансову іiі складову. Фінансова безпека баків $\epsilon$ індикативною компонентою ефективності та результативності 
дії механізмів ризик-менеджменту, операційного та фінансового менеджменту, менеджменту персоналу та маркетингу, що забезпечують нормальне функціонування банків. При цьому, питання фінансової безпеки в сучасній банківській практиці, яка знаходиться під впливом мінливих умов ускладнення фінансових відносин, зокрема в умовах глобалізації характеру грошових потоків, характеру відносин власності, характеру клієнтської бази набувають особливої актуальності.

Аналіз останніх досліджень і публікацій. Питанням економічної природи фінансової безпеки, причин ii порушення та заходів забезпечення на рівні держави, інституційних секторів та окремих суб'єктів підприємництва приділено увагу такими вченимиекономістами, як: C.I. Адаменко, О.I. Барановський, I.О. Бланк, 3.С. Варналій, М.М. Єрмошенко та іншими. У розробку питань визначення специфіки фінансової безпеки в банківській сфері, iї оцінки та забезпечення в банківських установах вагомий внесок зробили такі науковці, як: O.I. Барановський, М.М. Барилюк, Т.М. Болгар, Р.С. Вовченко, П.А. Герасимов, А.О. Спіфанов, В.В. Коваленко, О.М. Колодізєв, Ю.В. Ніколаєнко, О.Л. Пластун, С.М. Побережний та інші. Високо оцінюючи внесок вченихекономістів у вирішення проблем забезпечення фінансової безпеки на різних рівнях і в різних сферах економіки, зазначимо, що питання ефективного забезпечення фінансової безпеки банків залишається дискусійним, а тому потребує подальшого дослідження.
Метою статті $\epsilon$ обгрунтування сутнісних характеристик фінансової безпеки банків, дослідження ризиків, що впливають на фінансову безпеку банківської діяльності та вибір найбільш ефективного інструментарію забезпечення фінансової безпеки вітчизняних банків.

Виклад основних результатів. Процес успішного функціонування i розвитку банку в умовах ринкової економіки неможливий без забезпечення достатнього рівня фінансової безпеки та ефективного управління ним. Крім того, суттєвість значення рівня достатності фінансової безпеки банків в Україні зумовлено тим, що фінансово стійкі та фінансово безпечні банки ефективно вирішують питання забезпечення їх ресурсної, кадрової, інформаційної та фізичної безпеки [1]. На сьогодні існують різні підходи до трактування дефініції «фінансова безпека». Однак, найбільш деталізоване уявлення про фінансову безпеку дається О. Барановським [2, с.258], який акцентує, що фінансова безпека - це важлива складова частина економічної безпеки індивіда, домашнього господарства, суб'єкта господарювання, підприємництва, галузі господарського комплексу, сектору національної економіки, економічної системи, регіону, держави, суспільства (а отже, і національної безпеки), міждержавних економічних утворень і світового господарства загалом, що базується на незалежності, ефективності й конкурентоспроможності фінансово-кредитної сфери, яка відображається через систему критеріїв і показників її стану, що характеризують збалансованість фінансів, 
достатню ліквідність активів i наявність необхідних грошових, страхових і золотовалютних резервів.

Виділяють такі ключові сутнісні характеристики фінансової безпеки банків [3, с. $42 ; 4$, с. 88$]$ :

$\epsilon$ основним елементом економічної безпеки банків;

забезпечує рівноважний i стійкий фінансовий стан банку;

сприяє ефективній діяльності банку та забезпечує його розвиток $\mathrm{i}$ стійкість (зростання ринкової вартості, фінансові переваги);

дозволяе на ранніх стадіях визначати проблемні місця в діяльності банку;

нейтралізує кризові ситуації та попереджує банкрутство.

характеризується кількісними та якісними показниками, при цьому показники фінансової безпеки повинні мати порогові значення, за якими можна судити про ступінь фінансової безпеки банку;

забезпечує захищеність фінансових інтересів банку, його клієнтів і акціонерів.

На банківську систему загалом і на окремі банки впливає велика кількість різноманітних ризиків як внутрішнього (якість кредитного портфеля, рівень та компетенція менеджменту, структура активів і пасивів, залежність від інсайдерів тощо), так і зовнішнього характеру (нормативне регулювання, грошово-кредитна політика, довіра до банківської системи, стан економіки держави та ін.), що обумовлює необхідність постійного контролю за станом кризового середовища як банківської системи, так і окремих банків.
Тому, основною метою фінансової безпеки банку $є$ забезпечення конкурентоспроможності як окремого банку, так і банківської системи загалом на ринку банківських послуг і недопущення можливості отримання збитків або втрати частини прибутків унаслідок реалізації внутрішніх та зовнішніх загроз [5].

Досягнення означеної мети уможливлюється через визначення потенційних проблеми в діяльності банку, їх усуненні та здійсненні контролю за результативністю заходів щодо забезпечення фінансової безпеки (табл. 1).

Значною проблемою для фінансової безпеки банків є різні злочинні дії як 3 боку клієнтів, так і з боку працівників банків. Сфера злочинних дій з боку клієнтів перебуває у сфері відповідальності служб безпеки банків, а список потенційних злочинних дій відомий заздалегідь. Тобто банк може усунути можливості для таких дій шляхом проведення попереджувальних заходів.

Набагато складніша ситуація із випадками навмисної бездіяльності клієнтів та їх діями у рамках правового поля, які можуть спричинити негативні наслідки для банку. Такі ситуації отримали назву моральних ризиків, які здійснюють істотний вплив на рівень фінансової безпеки банків.

Моральний ризик науковцями розглядається як:

- д дії економічних агентів з максимізації їх власної вигоди на шкоду іншим суб'єктам економіки унаслідок нерівності інформації та розходження інтересів, що проявляються в зміні поведінки однієї із сторін контракту [7, c.50]; 
Таблиця 1

Загрози фінансовій безпеці банків у сфері кредитування та методи їх усунення

\begin{tabular}{|c|c|c|}
\hline Проблема (загроза) & $\begin{array}{c}\text { Теоретичний метод усунення за- } \\
\text { грози }\end{array}$ & Практика вітчизняних банків \\
\hline $\begin{array}{l}1 . \text { Зростання } \\
\text { проблемної } \\
\text { заборгованості } \\
\text { в цілому. } \\
2 . \quad \text { Зростання } \\
\text { проблемної } \\
\text { заборгованості } \\
\text { за окремими гру- } \\
\begin{array}{l}\text { пами позичальни- } \\
\text { ків }\end{array}\end{array}$ & $\begin{array}{l}\text { - перегляд та коригування } \\
\text { кредитної політики; } \\
\text { - формування } \\
\text { під кредитні операції; } \\
\text { - дезервів } \\
\text { портфеля; } \\
\text { - врахування в методиках аналізу } \\
\text { кредитоспроможності галузевих } \\
\text { особливостей позичальників; } \\
\text { - участь в роботі кредитних бюро } \\
\text { (стосується кредитування фізичних } \\
\text { осіб); } \\
\text { - політика “обмеженого” зростан- } \\
\text { ня; } \\
\text { - контроль за позичальниками } \\
\text { та їх фінансовим станом }\end{array}$ & 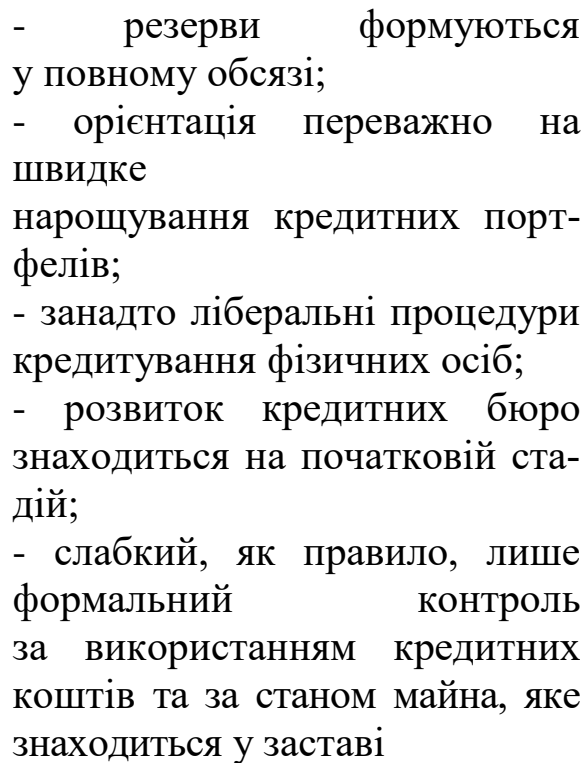 \\
\hline
\end{tabular}
Джерело: [6, с.76]

імовірність того, що одна зі сторін угоди надала неправдиву інформацію про свої активи, зобов'язання або кредитоспроможність чи наявність стимулу прийняти високі ризики у відчайдушній спробі отримати прибуток однієї зі сторін контракту [8];

- $\quad$ ситуацію, коли одна сторона $\epsilon$ відповідальною за інтереси другої, але намагається перш за все реалізувати власні інтереси [9, с. 142].

До можливих наслідків дії моральних ризиків на діяльність банку варто віднести: портфеля;

погіршення якості кредитного збільшення обсягів проблемних і безнадійних кредитів;

втрату рівня конкурентоспроможності банку;

падіння захищеності банку через здійснення операцій підвищеної ризикованості;
- $\quad$ втрату фахових працівників; виникнення загрози стабільності.

Моральні ризики варто розглядати у дворівневій площині, на макро- та мікрорівнях. При цьому, на макрорівні моральний ризик формується під впливом низки чинників, які притаманні саме цьому рівню, а саме: структури економіки; ступеня концентрації іiі окремих галузей; ринкових чинників (ліквідність банківського сектору; використовувані інструменти залучення і розміщення ресурсів банками; специфіка оцінювання діяльності банків тощо); регулятивних чинників (економічні нормативи; обмеження; ліміти, що можуть установлюватися центральним банком для комерційних банків у сфері реалізації їхньої кредитної та інвестиційної політики).

Виходячи із сутності моральних ризиків, C.I. Адаменко пропонує розподіл моральних ризиків $\mathrm{y}$ 
банківській діяльності саме за впливом зовнішніх та внутрішніх факторів (рис. 1) .

Боротьба з моральними ризиками, що виникають у банківській діяльності може здійснюватися через використання як внутрішніх методів (контроль за позичальниками, ведення бази кредиторів, страхування ліквідності, загроза банкрутства позичальників, ефективна заробітна плата, оплата праці за результатами, відповідальність керівництва банку), так зовнішніх методів (нормативне регулювання, контроль за діяльністю банку з боку материнської компанії, нагляд з боку центрального банку, державна політика в грошовокредитній сфері). Для забезпечення фінансової безпеки банкам необхідний $€$ певний інструментарій, який дає змогу на постійній основі здійснювати діагностичні і превентивні дії, спрямовані на підтримку належного рівня фінансової безпеки.

Хоча банківська діяльність підлягає регулюванню з боку держави, банк, як господарюючий суб'єкт, має економічну самостійність, а тому може самостійно обирати інструменти оцінки та забезпечення своєї фінансової безпеки. Такими інструментами є: фінансовий аналіз; фінансове планування; фінансове регулювання та фінансовий контроль.

Моральні ризики в банківській діяльності

Обумовлені внутрішніми факторами

Наявність гарантованого доступу до фінансових ресурсів

Асиметричність інформації у відносинах “банк-персонал

Необ'єктивність внутрішнього аудиту та контролю

Необачлива діяльність менеджменту

Рис. 1. Ранжування моральних ризиків в банківській діяльності за впливом зовнішніх та внутрішніх факторів

$$
\text { Джсерело: [7, с.51] }
$$

Основними складовими фінансової безпеки банку $є$ : система управління ризиками, фінансова стійкість, рівень капіталізації та достатність власного
Обумовлені зовнішніми факторами

Наявність фонду гарантування вкладів населення

Ризики, пов'язані з діяльністю наглядових органів

Поведінка клієнтів

Залежність банку від ключових клієнтів капіталу для покриття банківських ризиків, якість кредитного та інвестиційного портфелів i, як наслідок, банківських активів загалом, рівень 
рентабельності банківської діяльності, фінансовий потенціал, рівень корпоративного контролю, конкурентоспроможність банку та банківських послуг на ринку, частка іноземного капіталу у статутному капіталі банку тощо .

Тому, на рівні окремих банків фінансова безпека повинна забезпечуватись якісним підбором кадрів банку, організацією роботи внутрішнього підрозділу безпеки відповідно до покладених на нього завдань і принципів його роботи.

На рівні держави банківська безпека забезпечується шляхом визначення комерційних, організаційних технологічних i соціальних пріоритетів (суб'єкта підприємництва, галузі, регіону); нормативно-правового забезпечення безпеки банків; налагодження системи оцінок і контролю реальних і потенційних фінансових загроз життєвим інтересам держави; забезпечення ефективного функціонування Національного банку України.

Аналіз та систематизація економічної літератури дозволили визначити низку заходів, які повинні бути виконані з метою забезпечення фінансової безпеки банків $[10 ; 11 ; 12]$ :

ідентифікацію ризиків і пов'язаних з ними потенційних небезпек;

- $\quad$ визначення індикаторів

- впровадження

системи діагностики та моніторингу стану фінансової безпеки; розробку заходів, спрямованих на забезпечення фінансової безпеки банку, як в коротко- строковому, так і в довгостроковому періодах;

контроль за виконанням запланованих заходів;

аналіз виконання заходів, їх оцінка корегування;

- $\quad$ ідентифікацію загроз банку і корегування індикаторів залежно від зміни стану зовнішнього середовища, цілей і завдань банку;

- моніторинг і облік факторів, що визначають загрози фінансовій діяльності банку;

- $\quad$ формування оптимальної структури боргових зобов'язань (банку та його клієнтів);

протидія злочинним зазіханням на фінансові ресурси банку;

визначення причин та усунення наслідків реалізованих загроз;

забезпечення балансу доходів та витрат у діяльності банку;

забезпечення ліквідності та платоспроможності банку;

- забезпечення фінансової стійкості і фінансової незалежності банку;

збереження фінансових можливостей банку у безпечному стані в умовах дії різноманітних небезпек i загроз.

За умов пошуку оптимального варіанту одночасного забезпечення фінансової безпеки банківської діяльності, та необхідністю економічного зростання і ринкової ефективності постає важливе питання вибору найбільш ефективного інструментарію регулювання банківської діяльності, який буде чинити стимулюючий вплив на банківську систему та забезпечувати позитивний ефект для всіх суб'єктів економіки. 
Саме регулювання банківської діяльності за умов економічної нестабільності повинно сприяти підвищенню рівня довіри до національної банківської системи та іï елементів, сприяти довгостроковій стійкості банківського сектору, що забезпечить належний рівень фінансової безпеки держави.

Отже, своєчасне виявлення зовнішніх та внутрішніх загроз $€$ основою для організації дієвого процесу забезпечення фінансової безпеки банку. Основними заходами щодо запобігання зовнішніх та внутрішніх загроз $\epsilon$ посилення державного регулювання банківської сфери, запровадження нових методів і технології обробки та аналізу інформації для оцінки і забезпечення фінансової безпеки окремого банку, а також належний рівень фінансового контролю як за фінансовими ресурсами та здійсненими операціями, так і за діями самого персоналу банку. Такі заходи повинні бути розроблені із застосуванням мінімальних затрат ресурсів та часу для досягнення бажаного результату.

Висновки. На основі поведеного дослідження можна зробити висновок про те, що побудова ефективно діючої системи забезпечення фінансової безпеки банків $\epsilon$ необхідною умовою як стабільності окремо взятого банку, так і банківської системи України загалом.

До основних інструментів, які можуть бути використані для аналізу рі- вня фінансової безпеки, можуть бути віднесені: фінансове планування, фінансовий аналіз, фінансове регулювання, фінансовий контроль, а також банківське регулювання, банківський нагляд і банківський контроль.

Моральні ризики мають істотний вплив на рівень фінансової безпеки банків. Зважаючи на специфіку моральних ризиків, значний рівень скритності i непередбачуваності, банкам необхідно приділяти максимум уваги їх обліку, аналізу та оцінці.

Забезпечення безпеки банків в Україні має здійснюватися на двох рівнях: на рівні окремого банку на підставі реалізації заходів банківського менеджменту та на рівні банківської системи на підставі реалізації державних заходів, спрямованих на захищеність інтересів банку (банківської системи у цілому) від внутрішніх та зовнішніх загроз. Серед заходів для середнього рівня фінансової безпеки банків слід назвати: підсилення державного регулювання банківської сфери, вдосконалення методичної бази оцінки рівня фінансової безпеки банку; зміцнення позиції державних банків у реалізації стратегії економічного розвитку країни; наближення діяльності вітчизняних банків до міжнародних стандартів, підвищення ефективності діяльності та фінансової стійкості банків шляхом поліпшення якості корпоративного управління.

\section{Список використаної літератури}

1. Kvasnytska, R., Matviichuk, L., Dotsenko, I. \& Kovalenko, Y. (2019). Indicative Express-Estimation Of Financial Security Of Banking Activity. Proceedings of the 6th International Conference on Strategies, Models and Technologies of Economic 
Systems Management (SMTESM 2019). Vol.\#95. Atlantis Press.: https://www.atlantis-press.com/proceedings/smtesm-19/125917634.

2. Барановський O.I. Філософія безпеки: монографія в 2-х томах. Том 1. Основи економічної і фінансової безпеки економічних агентів. К.: УБС НБУ. 2014. $831 \mathrm{c}$.

3. Побережный С.Н., Дадашев Б.А., Пластун А.Л. Модели и методы обеспечения банковской безопасности: монография. Сумы: ГВУЗ «УАБД НБУ». 2010. 239 c.

4. Квасницька Р.С., Левчук Ю.Л. Характеристики сутності фінансової безпеки банку та підходів до іiі оцінки. Матеріали міжнародної науковопрактичної конференції «Universum View 14. Economics and management» (03 лютого 2019 р., м. Рівне).Вінниця: ТОВ «Нілан-ЛТД». 2019. С.30-36.

5. Барановський О. Безпека банківської сфери. Вісник Національного банку України, 2014. № 6. С.40-47.

6. Вовченко Р.С. Чинники і загрози фінансовій безпеці банківського сектору національної економіки. Збірник наукових праць «Фінансово-економічна діяльність: проблеми теорії та практики». 2013. № 1. С.75-83.

7. Адаменко С.I. Характеристика та класифікація загроз у банківській системі України. Стратегічна панорама, 2004. № 4. С.48-52.

8. Побережний С. М., Пластун О. Л., Болгар Т. М. Фінансова безпека банківської діяльності: навч. посібн. Суми: ДВНЗ «УАБС НБУ». 2010. 112 с.

9. Зубок М. І. Безпека банківської діяльності : навч. посібн. К. : Вид-во КНЕУ. 2002. 190 c.

10. Вовк В.Я. Теоретичні засади забезпечення фінансової безпеки банку. Проблеми економіки, 2012. № 4. С.200-204. 